\title{
Foliar application of Zinc and Boron improved the productivity and net returns of maize grown under rainfed conditions of Pothwar plateau
}

\author{
Allah Wasaya ${ }^{1,2^{*}}$, Muhammad Shahzad Shabir ${ }^{3}$, Mubshar Hussain ${ }^{1,4^{*}}$, Muhammad Ansar ${ }^{3}$, \\ Ahsan Aziz ${ }^{5}$, Waseem Hassan ${ }^{6}$, and Ijaz Ahmad
}

${ }^{1}$ College of Agriculture, Bahauddin Zakariya University, Bahadur Sub-Campus Layyah, Pakistan. ${ }^{2}$ Key Laboratory of Agricultural Water Resources, The Center for Agricultural Resources Research, Institute of Genetics and Developmental Biology, The Chinese Academy of Sciences, 286 Huaizhong Road, Shijiazhuang 050021, Hebei, China. ${ }^{3}$ Department of Agronomy, PMAS-Arid Agriculture University Rawalpindi, Pakistan. ${ }^{4}$ Department of Agronomy, Bahauddin Zakariya University Multan, Pakistan. ${ }^{5}$ Department of Agronomy, University College of Agriculture, University of Sargodha, Pakistan. ${ }^{6}$ Department of Soil and Environmental Sciences, Muhammad Nawaz Sharif University of Agriculture Multan, Pakistan. ${ }^{7}$ Soil Conservation Group of Agriculture Department, ADC Colony, Rawalpindi Road, Talagang, Pakistan. *Corresponding author: wasayauaf@gmail.com; mubashiragr@gmail.com

\begin{abstract}
Under rainfed conditions, farmers rarely use micro-nutrients for crop production, due to which soils become deficient especially in zinc (Zn) and boron (B). Secondly, farmers apply nutrients through soil application but scarcity/less availability of moisture make the nutrients unavailable for crop plants. Under such circumstances, foliar application of $\mathrm{Zn}$ and B may play a key role for better crop growth and yield. Therefore this field study was conducted to investigate the role of $\mathrm{Zn}$ and $\mathrm{B}$ application alone and in combination through seed, soil and foliar application methods on growth, yield and net returns of maize grown under rainfed conditions. Results showed that combined application of $\mathrm{Zn}$ and B on foliage improved relative water contents, SPAD chlorophyll values, leaf area index (LAI), crop growth rate (CGR), and grain yield due to substantial expansion in entire yield related traits. Combined foliar application of $\mathrm{Zn}$ and $\mathrm{B}$ harvested $12 \%$ and $45 \%$ more yield compared with seed priming and control treatments, respectively. The foliar application of $\mathrm{Zn}$ and $\mathrm{B}$ in combination counteracted the low rainfall effect by producing higher relative water contents that helped in improving SPAD-chlorophyll values, LAI and CGR. Higher net returns and benefit: cost ratio was also obtained by foliar application of $\mathrm{Zn}$ and $\mathrm{B}$ in combination. In conclusion, combined foliar application of $\mathrm{B}$ and $\mathrm{Zn}$ improved maize yield due to significant expansion in allometric and yield related traits and thus improved net returns of maize grown under rainfed conditions of Pothwar plateu in Pakistan.
\end{abstract}

Keywords: Boron, Foliar application, Grain yield, Maize, Proline contents, Zinc 


\section{Introduction}

Maize (Zea mays L.) is considered as leading cereals in the world as far as its production per unit area is concerned (FAO, 2010). Among cereal crops of Pakistan, it ranks third after wheat and rice with annual production of 4.94 million tons and average yield of 4.32 tons per hectares from an area of 11.42 million hectares (Govt. of Pakistan, 2015). In Pakistan, its average yield is very low as compared to developed countries especially in rainfed region compared to irrigated areas (Govt. of Pakistan, 2009), due to low soil fertility and less availability of moisture at later crop growth stages. In addition to macronutrients like nitrogen $(\mathrm{N})$, phosphorus $(\mathrm{P})$, and potassium $(\mathrm{K})$, most of the cereals mainly maize suffer micronutrients dearth, zinc ( $\mathrm{Zn}$ ) and boron (B) in particular (Rashid and Rayan, 2004). Maize, being $C_{4}$ crop, is responsive to nutrients at all growth stages; and with adequate supply, it gives higher production (Song and Dia, 2000).

Crops grown in arid or semi-arid regions are mostly exposed to low soil fertility and exhibit multiple nutrient deficiencies due to low organic matter and alkaline calcareous nature that limit the crop production (Rafique et al., 2006). The rainfed soils of Pakistan are deficient in $\mathrm{Zn}$ and $\mathrm{B}$ as compared to irrigated areas. The prime reason of this deficiency is the unavailability of irrigation water to apply the nutrients to crop plants under field conditions in rainfed regions. Secondly, most of the Pakistani farmers do not apply micronutrient especially Zn and B (Kanwal et al., 2010) that lead to their deficiency in soil and causes yield reduction.

Zinc being essential nutrient plays a significant role in stomatal regulation and reducing the tensions of less water by creating ionic balance in plants system (Baybordi, 2006) and is involved in various physiological processes such as synthesis of protein and carbohydrates (Yadavi et al., 2014). Similarly, B application improves growth, and enhances stress tolerance in plants and improves grain production (Hussain et al., 2012). Both Zn and B play an important role in the basic plant functions like photosynthesis, protein and chlorophyll synthesis (Cakmak, 2008). These nutrients ( $\mathrm{Zn}$ and $\mathrm{B}$ ) are also involved in root growth, synthesis of proteins and carbohydrates, increase flower setting (Moeinian et al., 2011) and reduce kernel abortion especially (Wahid et al., 2011).

The nutrient deficiency can be corrected by applying micronutrient containing fertilizers. The nutrients can be applied to crop plants in a variety of ways like seed treatment, soil application and foliar spray. Every method has its advantages and disadvantages (Rehim et al., 2012), depending upon the soil and climatic conditions of the area. Soil application of $\mathrm{Zn}$ and B is highly helpful in improving the maize productivity (Kanwal et al., 2010). However, according to economic point of view, seed treatment and foliar application are better options because these are economical than soil application. Seed priming with different B solutions reduces time to $50 \%$ germination and improves the final germination percentage in rice (Farooq et al., 2011). Foliar application of micronutrients is 6 to 20 times more useful than the soil application and improves the nutrition (Arif et al., 2006). Foliar application of $\mathrm{Zn}$ reduces the micronutrient deficiencies and it is an efficient method because nutrients are easily absorbed through leaves and is best option to compensate micronutrient deficiencies in shorter period of time under rainfed regions (Nasiri et al., 2010). Foliar application of B at earlier, middle and later growth stages along with recommended dose of NPK resulted in higher maize food and fodder yield (Soomro et al., 2011). Similarly, in B and Zn deficient soils, their combined soil application significantly increased the plant height, root length, leaf area index, 
shoot and root dry weight and chlorophyll content (Panhwar et al., 2011).

Though the role of micronutrients, like $\mathrm{Zn}$ and $\mathrm{B}$, application in improving maize performance is well documented; however very little is known about the effect of combined application of B and $\mathrm{Zn}$ through different methods on maize performance grown under rainfed conditions. Therefore, this field study was designed to evaluate the role of $\mathrm{Zn}$ and $\mathrm{B}$ application alone and in combination with different methods in improving productivity and net returns of maize grown under rainfed conditions of Pothwar plateau.

\section{Materials and Methods}

\subsection{Experimental site}

This field experiment was conducted at University Research Farm Chakwal Road, PMAS-Arid Agriculture University Rawalpindi, Pakistan $\left(32.56^{\circ} \mathrm{N}, 72.52^{\circ} \mathrm{E}\right.$ and $513 \mathrm{~m}$ above sea level) during kharif season on sandy clay loam soil. The chemical properties of the 0-30 cm soil were as follows; $\mathrm{pH} 7.15$, EC $0.7 \mathrm{ds} \mathrm{m}^{-1}$, organic matter $0.42 \%$, available phosphorus (P) 4.25 ppm, available potassium (K) 80 ppm, B 0.9 ppm and $\mathrm{Zn} 1.93 \mathrm{ppm}$. The climate of the region is semi-arid, and the climatic data for the whole crop season are presented in Figure 1.

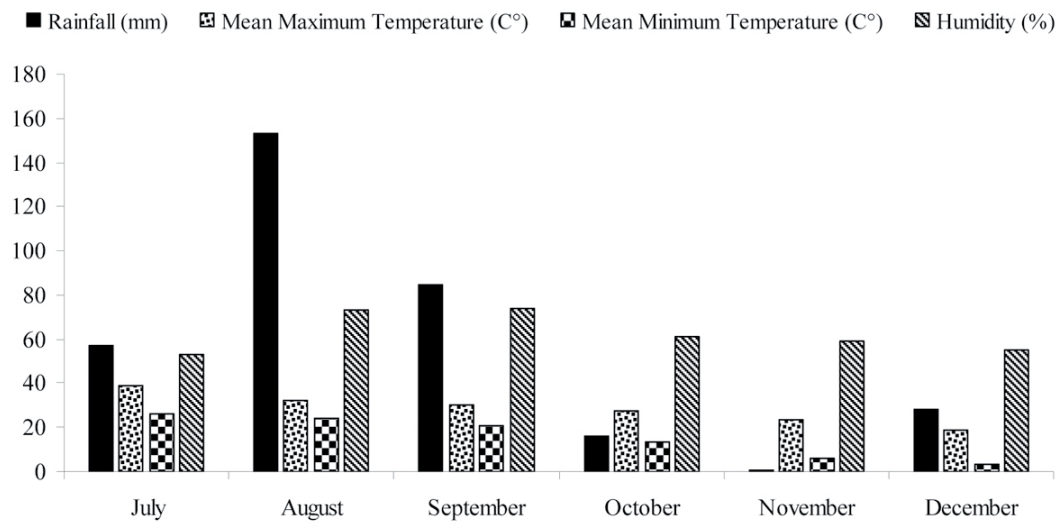

Figure 1. Climatic data for whole crop season

\subsection{Experimental details}

Seeds of maize variety Agaiti-2002 (recommended for rainfed cultivation) were obtained from National Agricultural Research Center, Islamabad, Pakistan and used as experimental material. B and $\mathrm{Zn}$ were applied alone and in combination by using three application methods viz. seed priming, soil application and foliar application. For seed priming, seeds were soaked in aerated solution of $1 \%$ zinc sulphate and
$0.01 \% \mathrm{~B}$ for $24 \mathrm{~h}$. The ratio of seed weight to solution volume was 1:5 $(\mathrm{g} / \mathrm{mL})$. After priming, seeds were rinsed thoroughly, dried with forced air near to their original weight under shade and stored at $5{ }^{\circ} \mathrm{C}$ until sowing. In soil application, $\mathrm{Zn}$ and $\mathrm{B}$ were applied to the soil at the time of sowing at the rate of 2 and $15 \mathrm{~kg} \mathrm{ha}^{-1}$, respectively while control plots received nothing. For foliar application, $\mathrm{Zn}$ and B were applied as a foliar spray of $1 \%$ zinc sulphate and $0.01 \% \mathrm{~B}$, when crop reached at the 5-leaf stage (V5) and silking 
stage (R1). In case of control, seeds were soaked in water during seed priming and plants were sprayed with water regarding foliar application of nutrients. Granular zinc sulphate (33\%) for $\mathrm{Zn}$ and Indiplex B (17\%) a product of "United Distributors Pakistan Limited" having B (17\%) in the form of fully water soluble formulation were applied according to the treatments. The experiment was laid out according to randomized complete block design with split plot arrangement by keeping nutrient application in main plots and application methods in sub plots. The experiment was replicated four times having a net plot size of $6 \mathrm{~m} \times 4.5 \mathrm{~m}$.

\subsection{Crop husbandry}

Seedbed was prepared with the help of tractor mounted cultivator followed by planking four days after occurrence of rainfall when the field reached to workable moisture conditions. The crop was sown on August 13, 2012 on well prepared seedbed with single row hand drill at a seeding rate of $25 \mathrm{~kg} \mathrm{ha}^{-1}$ and a seedling depth of $2 \mathrm{~cm}$ keeping row to row distance of $75 \mathrm{~cm}$. For maintaining an appropriate plant to plant distance of $20 \mathrm{~cm}$, thinning was made at 4-leaf stage. Based on soil testing, all the treatments received $150 \mathrm{~kg} \mathrm{ha}^{-1} \mathrm{~N}$ and $100 \mathrm{~kg} \mathrm{ha}^{-1} \mathrm{P}_{2} \mathrm{O}_{5}$ as a basal dose by using urea and di-ammonium phosphate (DAP) respectively. Both the fertilizers were applied at the sowing time, because crop was not applied supplemental irrigation and fully grown under rainfed conditions. Weeds were controlled by manual hoeing at 4-leaf stage. Furadan 3G (Carbofuran) was applied at 4-leaf stage to control the attack of shoot borer. Crop was harvested manually at physiological maturity, sundried for 10 days and then shelled using mechanical sheller.

\subsection{Measurements}

Crop allometry

Above ground biomass and leaf area index (LAI) were determined from five consecutive plants having an area of $0.75 \mathrm{~m}^{2}$, cut at ground level from the central rows of each experimental unit. The sample were collected at 25 days interval starting from 40 days after sowing (DAS) i.e. at V8 ( $8^{\text {th }}$ leaf stage) and terminated at 115 DAS i.e. at R6 (physiological maturity). Total leaves from all plants were separated from stem for measurement of leaf area, measured using leaf area meter (CI-202 Area Meter, CID, INC, USA). On the basis of leaf area, LAI was then calculated as a ratio of leaf area to the land area. Then, the entire plant biomass was oven-dried at $70{ }^{\circ} \mathrm{C}$ to a constant weight for $48 \mathrm{~h}$ which was then used to determine crop growth rate (CGR) following Hunt (1978).

SPAD chlorophyll and relative water contents

Ten plants were randomly selected from each experimental unit at R1 (silking) stage and SPAD chlorophyll value was measured non-destructively with the portable SPAD-502 Chlorophyll Meter (Minolta Co., Ltd.) from the flag leaf of each plant, and then averaged. During measurements with the SPAD-502, the sensor head was shaded with the operator's own body as recommended by the manufacturer to avoid direct sunlight from reaching the instrument.

To determine leaf relative water contents (RWC), three plants from each experimental unit were randomly selected and their youngest leaves were harvested and then weighed to measure fresh weight (FW). Then, the leaves were immersed in deionized water in beakers for $24 \mathrm{~h}$ and fully turgid weight (TW) 
was measured. Then, the leaves were oven dried at $70{ }^{\circ} \mathrm{C}$ until constant weight and dry weight (DW) of leaves was measured. Leaf RWC (\%) were calculated using the below given formula:

$\mathrm{RWC}=(\mathrm{FW}-\mathrm{DW} / \mathrm{TW}-\mathrm{DW}) \mathrm{X} 100$

Yield and related traits

At physiological maturity each experimental unit was harvested manually, sun dried for 8 days and tied into small bundles. When bundles were fully dried, these were weighed to record biological yield and then converted into $\mathrm{tha}^{-1}$. After recording biological yield, the cobs and stalk were separated. Ten cobs were randomly selected from each experimental unit to measure cob length $(\mathrm{cm})$. Cobs were then shelled with the help of mechanical sheller and weighed to record grain yield per plot, which then converted into $\mathrm{t} \mathrm{ha}^{-1}$. 1000-grains were counted from each shelled plot and weighed to determine 1000-grain weight. Harvest index (HI) was estimated as a ratio between grain and biological yield and expressed in percentage (\%).

\subsection{Statistical analysis}

Data collected using standard procedures were statistically analyzed using Statistix 8.1 software using tukey test. Analysis of variance technique and tukey test at 5\% probability level was used to compare the differences among treatment's means (Steel et al., 1997). Moreover, Microsoft Excel Program was used for the graphical presentation of data using standard error ( \pm S.E.).

\subsection{Economic analysis}

An economic analysis was carried out to assess the economic feasibility of different nutrient treatments and application methods used. Total expenses for growing maize were included primary tillage operations, land rent, seedbed preparation, seed, sowing, fertilizers, nutrient application, weeding, harvesting and shelling of crop. Gross income was estimated according to current market price for the maize grain in the country. Moreover, net income was worked out by deducting the total expenses from gross income while benefit-cost ratio (BCR) was calculated as a ratio of gross income to total expenses by using the methodology as described in CIMMYT (1988).

\section{Results}

Different nutrient treatments, application methods and their interaction significantly affected the allometric traits such as LAI and CGR in maize crop. Foliar application of both $\mathrm{Zn}$ and $\mathrm{B}$ in mixture produced higher LAI compared with other nutrient treatments and application methods while reduced LAI was recorded in control plots where neither of the nutrients $(\mathrm{Zn}, \mathrm{B})$ was applied (Figure 2). Similarly, maximum CGR was observed at 90 DAS, after which it started to decline with higher value under soil applied B and $\mathrm{Zn}$ mixture. Maize grown without micronutrient application produced less CGR; however, improvement in CGR was observed with application of $\mathrm{B}$ and $\mathrm{Zn}$ with higher value under soil application, which was at par with foliarly applied $\mathrm{Zn}$ and B mixture (Figure 3).

Different nutrients treatments, methods of application and their interaction significantly affected leaf relative water contents (RWC) and SPAD chlorophyll (Table 1). 


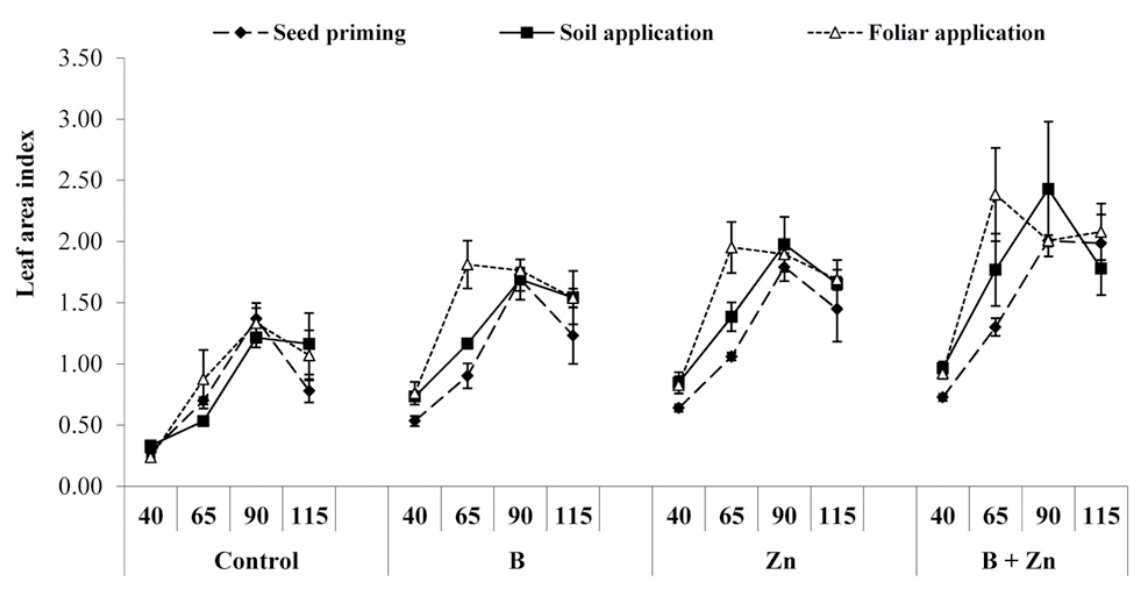

Days after sowing

Figure 2. Leaf area index as affected by nutrients treatments and application methods \pm S.E.

Application of both $\mathrm{Zn}$ and $\mathrm{B}$ in combination improved RWC in maize. The foliar application of $\mathrm{Zn}$ and $\mathrm{B}$ in combination recorded higher leaf RWC while lower RWC contents were recorded in control plots (Table 1). Similarly, higher SPAD chlorophyll value was observed in maize grown by the application of both $\mathrm{Zn}$ and $\mathrm{B}$ in mixture with minimum SPAD chlorophyll grown in control treatment. However, foliar application of nutrients improved SPAD chlorophyll compared with soil application and seed priming with minimum value observed in seed priming (Table 1). Different nutrients and their methods of application had significant effect on cob length and number of grains per cob (Table 2). Among application methods, foliar application and nutrient treatments, combined application of $\mathrm{Zn}$ and B improved cob length and number of grains per cob compared with other treatments (Table 2). Regarding interaction among application methods and treatments application, combined foliar application of $\mathrm{Zn}$ and $\mathrm{B}$ improved cob length and number of grains per cob followed by $\mathrm{Zn}$ alone; however, maize produced smaller cobs with lesser number of grains per cob in control treatments (Table 2).

Nutrient treatments, application methods and their interaction significantly affected 1000-grain weight, grain and biological yield (Table 3,4). Application of $\mathrm{Zn}$ and $\mathrm{B}$ mixture improved 1000-grain weight followed by sole applied $\mathrm{Zn}$ and B compared with control (Table 3). Similarly, maize grown through foliar application of nutrients produced healthy seed and resulted in higher 1000- grain weight compared with seed priming and soil application (Table 3). However, foliar application of $\mathrm{Zn}$ and $\mathrm{B}$ mixture improved 1000 -grain weight followed by sole application of $\mathrm{Zn}$ and B through soil and foliage; while, non-availability of nutrients caused reduction in 1000-grain weight (Table 3). Similarly, plants fertilized with Zn, B mixture produced more grain yield than other nutrient treatments and produced $45 \%$ more yield than control (Table 3). Similarly, foliar application produced about $9 \%$ higher yield than seed priming. However, plants grown through foliar application of $\mathrm{Zn}, \mathrm{B}$ mixture produced 54\% higher yield compared with all other nutrients treatments and application methods (Table 3). Maize grown with $\mathrm{Zn}$ and $\mathrm{B}$ mixture produced $39 \%$ higher yield than controlled treatments, while foliar application produced $6 \%$ higher biological yield compared with seed priming (Table 4). 


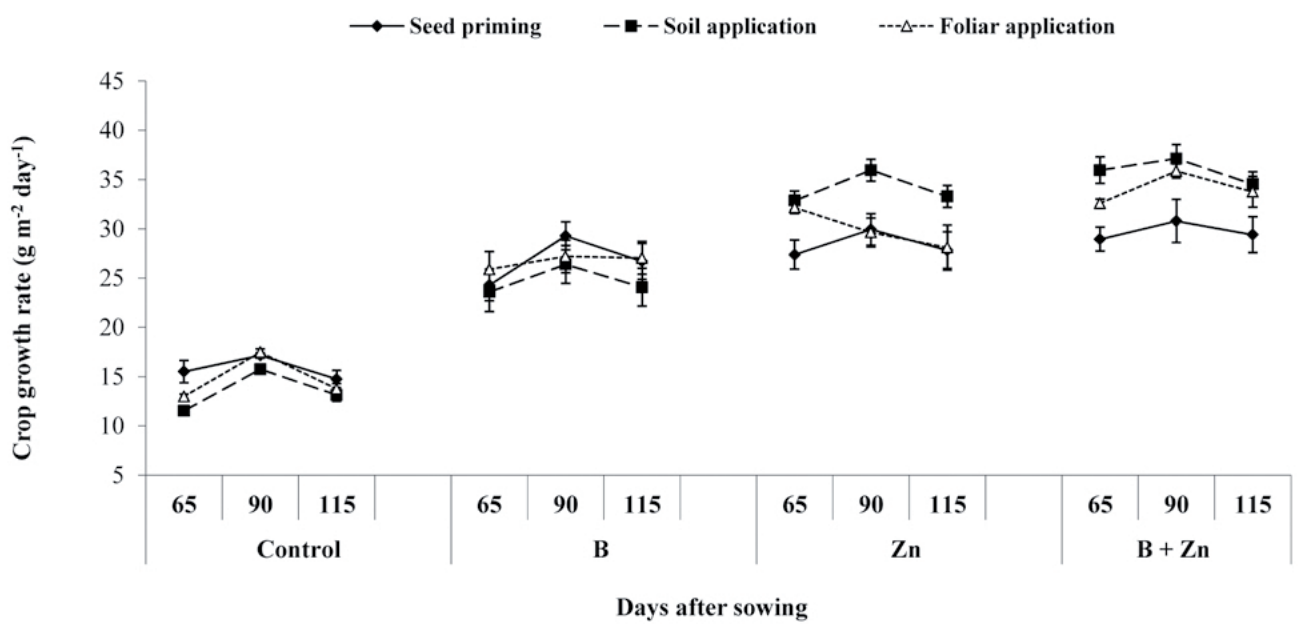

Figure 3. Crop growth rate $\left(\mathrm{g} \mathrm{m}^{-2}\right.$ day $\left.^{-1}\right)$ as affected by nutrients treatments and application methods \pm S.E.

It is indicated that foliar application of $\mathrm{Zn}$ and $\mathrm{B}$ mixture produced a higher biological yield compared with other treatments (Table 4). However, nutrient treatments and application methods had non-significant on harvest index of maize (Table 4). Economic analysis of the experiment indicated that application of $\mathrm{B}$ and $\mathrm{Zn}$ alone and in combination using all tested methods of application improved the net income and benefit: cost ratio (BCR) against control plots (Table 5). However, foliar application followed by soil application of $\mathrm{B}$ and $\mathrm{Zn}$ in combination observed the maximum gross income, net income and BCR of maize grown under rainfed conditions (Table 5).

Table 1. Effect of nutrient treatments and application methods on relative water contents and SPAD chlorophyll in maize



Means not sharing the same letter do not differ significantly at $p \leq 0.05 \pm \mathrm{S}$.E.

$\mathrm{DS}=$ dry seeding, $\mathrm{B}=$ boron application, $\mathrm{Zn}=$ zinc application, $\mathrm{B}+\mathrm{Zn}=$ zinc and boron application, $\mathrm{SP}=\mathrm{seed}$ priming, $\mathrm{SA}=$ soil application, $\mathrm{FA}=$ foliar application 
Table 2. Effect of nutrient treatments and application methods on cob length and grains per cob in maize

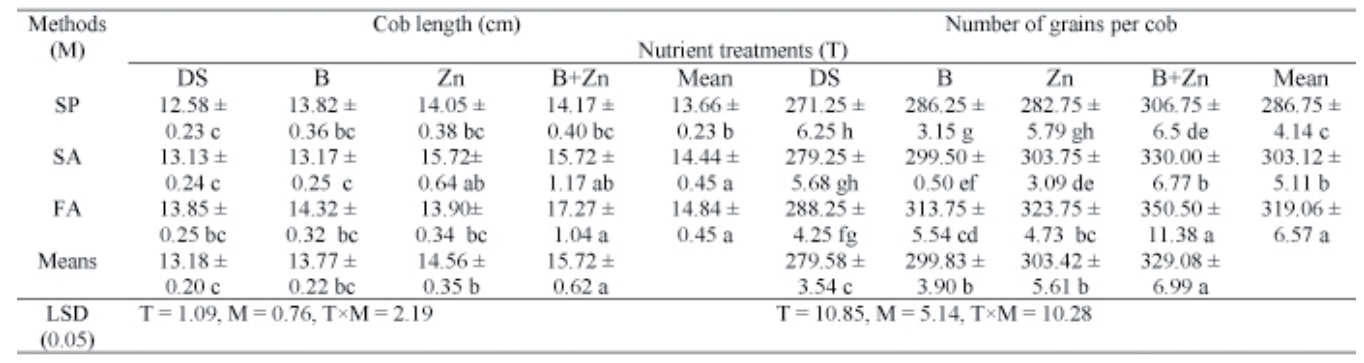

Means not sharing the same letter do not differ significantly at $p \leq 0.05 \pm$ S.E.

$\mathrm{DS}=$ dry seeding, $\mathrm{B}=$ boron application, $\mathrm{Zn}=$ zinc application, $\mathrm{B}+\mathrm{Zn}=$ zinc and boron application, $\mathrm{SP}=$ seed priming, $\mathrm{SA}=$ soil application, $\mathrm{FA}=$ foliar application

Table 3. Effect of nutrient treatments and application methods on 1000-grain weight and grain yield in maize

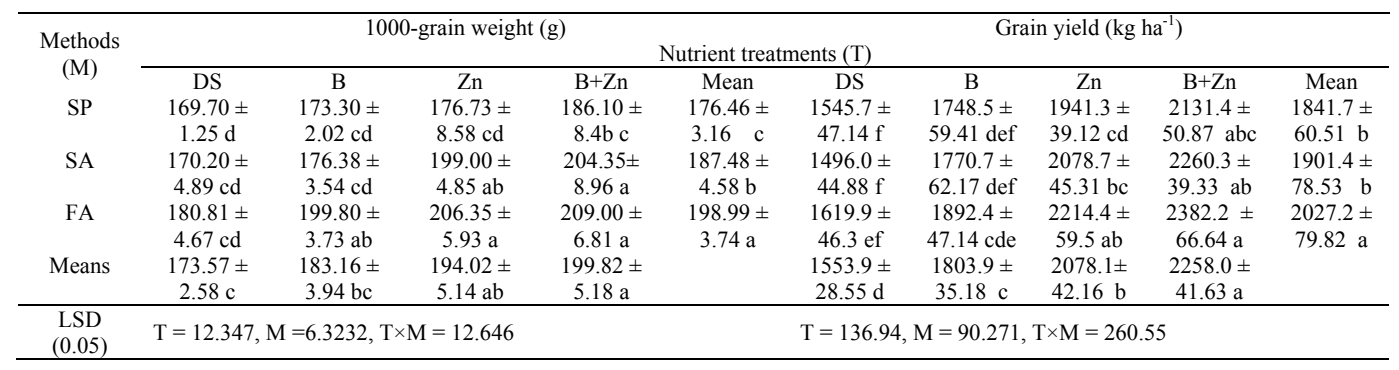

Means not sharing the same letter do not differ significantly at $p \leq 0.05 \pm$ S.E.

$\mathrm{DS}=$ dry seed sowing, $\mathrm{B}=$ boron application, $\mathrm{Zn}=$ zinc application, $\mathrm{B}+\mathrm{Zn}=$ zinc and boron application, $\mathrm{SP}=\mathrm{seed}$ priming, $\mathrm{SA}$ $=$ soil application, $\mathrm{FA}=$ foliar application, $\mathrm{T}=$ treatments, $\mathrm{M}=$ methods

Table 4. Effect of nutrient treatments and application methods on biological yield and harvest index in maize

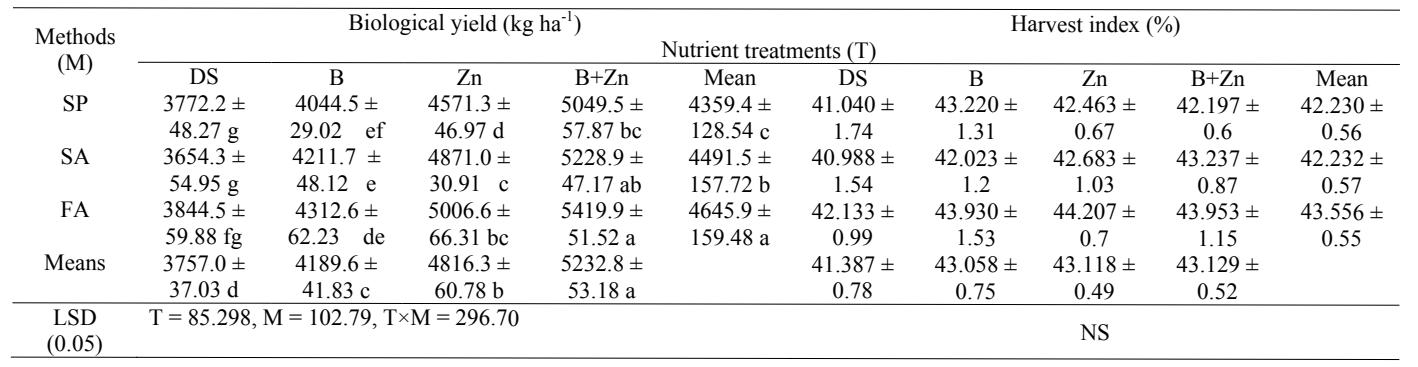

Means not sharing the same letter do not differ significantly at $p \leq 0.05 \pm \mathrm{S}$.E.

$\mathrm{DS}=$ dry seed sowing, $\mathrm{B}=$ boron application, $\mathrm{Zn}=$ zinc application, $\mathrm{B}+\mathrm{Zn}=$ zinc and boron application, $\mathrm{SP}=\mathrm{seed}$ priming,

$\mathrm{SA}=$ soil application, $\mathrm{FA}=$ foliar application, $\mathrm{T}=$ treatments, $\mathrm{M}=$ methods 
Table 5. Economic analysis for the effect of different nutrients treatments and application methods on maize performance under rainfed conditions

\begin{tabular}{lrrrr}
\hline Treatments & \multicolumn{1}{c}{$\begin{array}{c}\text { Total } \\
\text { Expenditure (US } \\
\text { \$ ha-1) }\end{array}$} & $\begin{array}{c}\text { Gross Income } \\
\left(\text { US } \$ h^{-1}\right)\end{array}$ & $\begin{array}{c}\text { Net Income (US } \\
\left.\$ h^{-1}\right)\end{array}$ & $\begin{array}{c}\text { Benefit-Cost } \\
\text { Ratio }\end{array}$ \\
\hline $\mathrm{T}_{1} \mathrm{M}_{1}$ & & & 1.26 \\
$\mathrm{~T}_{1} \mathrm{M}_{2}$ & 279.09 & 351.30 & 72.21 & 1.22 \\
$\mathrm{~T}_{1} \mathrm{M}_{3}$ & 279.09 & 340.01 & 60.91 & 1.32 \\
$\mathrm{~T}_{2} \mathrm{M}_{1}$ & 279.09 & 368.15 & 89.06 & 1.42 \\
$\mathrm{~T}_{2} \mathrm{M}_{2}$ & 280.23 & 397.39 & 117.16 & 1.35 \\
$\mathrm{~T}_{2} \mathrm{M}_{3}$ & 297.27 & 402.44 & 105.17 & 1.53 \\
$\mathrm{~T}_{3} \mathrm{M}_{1}$ & 280.91 & 430.08 & 149.17 & 1.49 \\
$\mathrm{~T}_{3} \mathrm{M}_{2}$ & 296.36 & 441.20 & 144.84 & 1.50 \\
$\mathrm{~T}_{3} \mathrm{M}_{3}$ & 315.45 & 472.43 & 156.97 & 1.64 \\
$\mathrm{~T}_{4} \mathrm{M}_{1}$ & 306.36 & 503.26 & 196.90 & 1.66 \\
$\mathrm{~T}_{4} \mathrm{M}_{2}$ & 291.14 & 484.41 & 193.27 & 1.70 \\
$\mathrm{~T}_{4} \mathrm{M}_{3}$ & 301.82 & 513.69 & 211.88 & 1.84 \\
\hline
\end{tabular}

$\mathrm{T}_{1}=$ Control, $\mathrm{T}_{2}=\mathrm{B}$ application $\mathrm{T}_{3}=\mathrm{Zn}$ application, $\mathrm{T}_{4}=\mathrm{B}+\mathrm{Zn}$ application, $\mathrm{M}_{1}=$ Seed priming, $\mathrm{M}_{2}=$ Soil application, $\mathrm{M}_{3}=$ Foliar spray

\section{Discussion}

Findings of this study indicated that foliar application of $\mathrm{Zn}$ and B improved dry matter and grain yield due to improvement in allometric traits, chlorophyll and relative water contents, and increase in yield components (Figure 2-3, Table 1-4). Maize, being $\mathrm{C}_{4}$ crop, is responsive to water and nutrients with high nutrient requirement at all growth stages; and with their adequate supply, it gives higher yield. But, the deficiency of nutrients especially $\mathrm{Zn}$ and $\mathrm{B}$ retards maize growth, hence reduces crop yield (Aref, 2011). Application Zn and B increased the photosynthesis and chlorophyll production that ultimately increases the dry weight and CGR leading to increased yield (Tariq et al., 2014).
Plant leaves act as a source for capturing light and assimilate production. In the current study, plants treated with foliar application of $\mathrm{Zn}$ and $\mathrm{B}$ mixture produced more LAI which might be due to increase in indole acetic acid hormone through $\mathrm{B}$ fertilization (Zhou et al., 2016). Moreover the substantial improvement in leaf RWC recorded 75 days after sowing (even under dry conditions; Figure 1) due to combined application of $\mathrm{Zn}$ and B might lead to higher LAI (Figure 2); as more leaf RWC are linked with leaf elongation due to higher turgidity. Leaf RWC is one of the indictors for yield improvement under low water conditions. Increased RWC under Zn and B mixture might be due to the fact that $\mathrm{Zn}$ is involved in stomatal regulation (Baybordi, 2006; Marschner, 2012). 
This might be due to leaf membrane stability (Sayed, 1998 ) by B application, as foliar appli־cation of micro-nutrients increases resistance in plants against abi-otic stresses (Tariq et al., 2004). It might also be due to increase in length and width of leaves, because $\mathrm{Zn}$ is involved in cell division (Zhu et al., 2015) which increases chlorophyll production (Samreen et al., 2013). Leaves plays a significant role and act as assimilatory organs therefore, reduction in LAI under controlled treatment and seed priming might be responsible for declined CGR and the reverse the case under foliar application of $\mathrm{Zn}$ and B mixture. Secondly, less chlorophyll in control treatment might be a possible reason for reduction in CGR. Higher CGR under foliar application of $\mathrm{Zn}$ and B mixture might be due to higher chlorophyll and LAI which leads to more biomass production. Increased CGR might be due to activation of different physiological processes like stomatal regulation, chlorophyll formation, enzyme activation and biochemical processes due to foliar application of micronutrients which resulted in increased dry matter production (Cakmak, 2008: Khan et al., 2010; Marschner, 2012). Foliar applied $\mathrm{Zn}$ and $\mathrm{B}$ increased the photosynthesis and chlorophyll production that ultimately increases the dry weight and CGR (Tariq et al., 2014). Moreover, the deficiency of these micronutrients cause discoloration of the foliage and necrosis of upper leaves (Monreal et al., 2015). Grain yield is the combined effect of different yield related traits. Increase in grain yield under foliar applied $\mathrm{Zn}$ and B mixture might be attributed to notable expansion in entire yield related traits (Table 1-3). Similarly, it might be due to higher translocation of carbohydrates to grains (Rajaie and Ziaeyan, 2009), which ultimately resulted in higher grain yield under foliar application of micronutrients. Increase in cob length by the foliar applied $\mathrm{Zn}$ and B mixture might be due to higher CGR (Figure 3). Increase in 1000 -grain weight through foliar application of $\mathrm{Zn}$ and B mixture might be attributed higher CGR (Figure $2)$. It is the fact that B application enhanced the pollen tube germination, grain setting which is involved in metabolism, increased root growth, synthesis of proteins carbohydrates (Moeinian et al., 2011) which improved the grain yield due by the application of B and other micronutrients (Tabrizi et al., 2009). Several researchers have also reported the higher 1000-grain weight in maize by the foliar application of micronutrients (Tabrizi et al., 2009). Increase in biological yield might be to due increased LAI, CGR, chlorophyll contents and grain yield. It might be due to activation of different physiological processes like stomatal regulation, chlorophyll formation, enzyme activation and biochemical processes through application of micronutrients (Cakmak, 2008; Khan et al., 2010) which resulted in high dry matter production.

Farmers adopt any technology by considering its economic feasibility in terms of cost and profit involved for growing any crop (Khan et al., 2012). Economic analysis of the current study showed that foliar application of both $\mathrm{B}$ and $\mathrm{Zn}$ found superior over other nutrient treatments and application methods to achieve maximum net income and BCR (Table 5) due to increased maize yield, which is main concern of the farmers.

\section{Conclusion}

Results of this field study disclosed that application of $\mathrm{Zn}$ and $\mathrm{B}$ had improved leaf chlorophyll and relative water contents, which in turn improved crop allometry, yield components and productivity of maize. Moreover, the foliar application of $\mathrm{Zn}$ and $\mathrm{B}$ in combination performed better and improved the net returns of maize grown under rainfed conditions of Pothwar plateu in Pakistan. 


\section{Acknowledgement}

The authors are grateful to the PMAS-Arid Agriculture University Rawalpindi, Pakistan for providing funds for completion of this research project as a part of postgraduate thesis.

\section{References}

Aref, F. 2011. Zinc and boron content by maize leaves from soil and foliar application of zinc sulfate and boric acid in zinc and boron deficient soils. Middle-East J. Sci. Res. 7, 610-618.

Arif, M., Chohan, M.A., Ali, S., Khan, S. 2006. Response of wheat to foliar application of nutrients. J. Agric. Biol. Sci. 1, 30-34.

Baybordi, A. 2006. Effect of Fe, Mn, Zinc and $\mathrm{Cu}$ on the quality and quantity of wheat under salinity stress. J. Water Soil Sci. 17, 140-150.

Cakmak, I. 2008. Enrichment of cereal grains with zinc: agronomic or genetic biofortification. Plant Soil. 302, 1-17.

CIMMYT. 1988. from agronomic data to farmer recommendations. An Economic Training Manual Completely Revised Edition Mexico D.F.

FAO. 2010. FAO Annual Report Results, Islamabad Pakistan.

Farooq, M., Rehman, A., Aziz, T., Habib, M. 2011. Boron nutrient priming improves the germination and early seedling growth of rice (Oryza sativa L.). J. Plant Nutr. 34, 1507-1515.

Government of Pakistan. 2009. Economic Survey of Pakistan, Ministry of Food, Agriculture and Livestock, Islamabad, pp: 20-25.

Government of Pakistan. 2015. Economic Survey of Pakistan, Ministry of food, Agriculture and Livestock (Federal Bureau of Statistics), Islamabad, pp: 23-44.
Hunt, R. 1978. Plant growth analysis. Studies in biology N0. 96. Edward Arnold, London, pp: 26-38.

Hussain, M., Khan, M.A., Khan, M.B., Farooq, M., Farooq, S. 2012. Boron application improves the growth, yield and net economic return of rice. Rice Sci. 19, 259-262.

Kanwal, S., Rahmatullah, Ranjha, A.M., Ahmad, R. 2010. Zinc partitioning in maize grain after soil fertilization with zinc sulfate. Int. J. Agric. Biol. 12, 299-302.

Khan, M.B., Farooq, M., Hussain, M., Shabir, G. 2010. Foliar application of micronutrients improves the wheat yield and net economic return. Int. J. Agric. Biol. 12, 953-956.

Khan, M.B., Khan M., Hussain, M., Farooq, M., Jabran, K., Lee, D.J. 2012. Bio-economic assessment of different wheat-canola intercropping systems. Int. J. Agri. Biol. 14, 769-774.

Marschner, P. 2012. Marschner's Mineral Nutritional of Higher Plants. 3rd Edition, Academic Press, London, UK.

Moeinian, M. R., Zargari, K., Hasanpour, J. 2011. Effect of boron foliar spraying application on quality characteristics and growth parameters of wheat grain under drought stress. Amer. Eur. J. Agric. Environ. Sci, 10, 593-599.

Monreal, C.M., DeRosa, M., Mallubhotla, S.C., Bindraban, P.S., Dimkpa, C. 2015. The application of nanotechnology for micronutrients in soil-plant systems. VFRC Report 2015/3. Virtual Fertilizer Research Center, Washington, D.C. pp: 44.

Nadergoli, M.S., Yarnia, M., Khoei, F.R. 2011. Effect of zinc and manganese and their application method on yield and yield components of common bean (Phaseolus vulgaris L. cv Khomein). Middle-East J. Sci. Res. 8, 859-865.

Nasiri, Y., Zehtab-Salmasi, S., Nasrullahzadeh, S., Najafi, N., Ghassemi-Golezani, K. 2010. Effects of foliar application of micronutrients ( $\mathrm{Fe}$ and $\mathrm{Zn}$ ) 
on flower yield and essential oil of chamomile (Matricaria chamomilla L.). J. Med. Plants Res. 4: 1733 -1737.

Panhwar, Q.A., Radziah, O., Khanif, Y.M., Naher. 2011. Application of boron and zinc in the tropical soils and its effect on maize (Zea mays L.) growth and soil microbial environment. Aust. J. Crop. Sci. 5, 1649-1654.

Rafique, E., Rashid, A., Rayan, J., Bhati, A.U. 2006. Zinc deficiency in rainfed wheat in Pakistan: magnitude spatial variability, management and plant analysis diagnostic norms. Comm. Soil Sci. Plant Anal. 37, 181-197.

Rajaie, M., Ziaeyan, A.H. 2009. Combined effect of zinc and boron on yield and nutrients accumulation in corn. Int. J. Plant Prod. 3, 35-440.

Rashid, A., Ryan, J. 2004. Micronutrient constraints to crop production in soils with Mediterraneantype characteristics: A Review. J. Plant Nutr. 27, 959-975.

Rehim, A., Farooq, M., Ahmad, F., Hussain, M. 2012. Band placement of phosphorus improves the phosphorus use efficiency and wheat productivity under different irrigation regimes. Int. J. Agri. Biol. 14, 727-733.

Samreen, T., Humaira, Shah, H.U., Saleem-Ullah, Javid, M. 2013. Zinc effect on growth rate, chlorophyll, protein and mineral contents of hydroponically grown mungbeans plant (Vigna radiate L.). Arabian J. Chem.

Sayed, S.A. 1998. Impacts of boron application on maize plants growing under flooded and unflooded conditions. Bio. plantarum. 41, 101-109.

Song, F.B., Dia, J.Y. 2000. Effect of drought stress on growth and development of female inflorescence and yield of maize. Acta agric. Uni. Jilinensis. 22, 18-22.
Soomro, Z., Baloch, P., Gandhai, A. 2011. Comparative effects of foliar and soil applied boron on growth and fodder yield of maize. Pak. J. Agri. Agril. Engg. Vet. Sci. 27, 18-26.

Steel, R.G.D., Torrie, J.H., Dickey, D.A. 1997. Principles and Procedures of Statistics. A biometrical approach.McGraw Hill Book Co., New York, USA. Pp: 400-428.

Tabrizi, E.F.M., Yarnia, M., Khorshidi, M., Ahmadzadeh, V. 2009. Effects of micronutrients and their application method on yield, crop growth rate (CGR) and net assimilation rate (NAR) of corn cv. Jeta. Int. J. food, Agric. Environ. 7, 611-615.

Tariq, A., Anjum, S.A., Randhawa, M.A., Ullah, E., Naeem, M., Qamar, R., Ashraf, U., Nadeem, M. 2014. Influence of zinc nutrition on growth and yield behaviour of maize (Zea mays L.) hybrids. Am. J. Plant Sci. 5, 2646-2654

Tariq, A.G., Rahmatullah M.A., Sabir, M., 2004. Mineral nutrition of fruit trees, pp. 28-33. Proc Plant$\mathrm{Nu} \neg$ trition Management for Horticultural Crops under Water-Stress Conditions, Agric Res Ins.

Wahid, M., Ahmad, W., Cheema, M., Saleem, M., Sattar, A., 2011. Impact of foliar applied boron on yield and yield components of spring maize (Zea mays L.) under drought condition. Soil and Crop Environ, Sci. pp: 382-383.

Yadavi, A., Aboueshaghi, R.S., Dehnavi, M.M., Balouchi, H. 2014. Effect of micronutrients foliar application on grain qualitative characteristics and some physiological traits of bean (Phaseolus vulgaris L.) under drought stress. Indian J. Fundamental Applied Life Sci. 4, 124-131. 
Zhou, T., Hua, Y., Huang, Y., Ding, G., Shi, L., $\mathrm{Xu}$, F. 2016. Physiological and Transcriptional Analyses Reveal Differential Phytohormone Responses to Boron Deficiency in Brassica napus Genotypes. Front. Plant Sci. 7:221. doi: 10.3389/ fpls.2016.00221
Zhu, J., Zhang, K.X., Wang, W.S., Gong, W., Liu, W.C., Chen, H.G. 2015. Low temperature inhibits root growth by reducing auxin accumulation via ARR1/12. Plant Cell Physiol. 56, 727-736. doi: $10.1093 / \mathrm{pcp} / \mathrm{pcu} 217$. 